9. Kruglov A. O proishozhdenii apriornyih predstavleniy u I. Kanta // Voprosyi filosofii. - 1998. - \# 10. - S.126-130.

10. Leontev A. Problemyi razvitiya psihiki. - M. : Izd-vo akademii ped. nauk RSFSR, 1959. - $496 \mathrm{~s}$

11. Petrovskiy A., Yaroshevskiy M. Osnovyiteoreticheskoypsihologii. M. : INFRA-M, 1998. $-528 \mathrm{~s}$.

12. Tatenko V. Naukova psykholohiia pro dushu i dukh liudskyi // Visnyk KIBiT. - 2012. - Vyp. 3. - S. 20-25.

Gennadiy Koval, post-graduate

National University of Zaporizhzhya, Zaporizhzhya, Ukraine
13. Tatenko V. Suchasna psykholohiia: teoretychno-metodolohichni problemy. - K. : NAU-druk, 2009. - 288 s.

14. Tkachenko O. Pryntsypy, katehorii i metodolohichni problemy psykholohii // Psykholohiia i suspilstvo. - 2009. - Vyp. 1(35). - S. 44-133.

15. Tkachenko A. Problema ishodnoy edinitsyi analiza psihiki $v$ istorii sovetskoy psihologii // Voprosyi psihologii. - 1980. - \#2. - S. 153-158.

Надійшла до редколегї̈ 04.07.19

\title{
CONCEPTUAL ASPECT OF THE DEFINITION OF THE TERM SOUL AS THE CATEGORY OF THEORETICAL PSYCHOLOGY
}

The problematic of the categorical aspect of the term of the soul through the prism of the principle of systematicity (organization) has been reviewed in the article. The problematic of the place of the category of a soul in the categorical apparatus of theoretical psychology have been shown through the context of general categories of the structure of the human - an organism, an individual, an individuality, a personality, the $I$, the subject. The problematic of analysis and disclosure of the meaning load of the specified of categories which is due to the application of the principle of determinism to their analysis has been noted. The possibility of building a hierarchical range of categories as levels of concretization (organization) of a mental structure of the one by analogy with respect to such a range of levels of concretization (organization) of a living that have been shown. It has been noted that specifics for a range of levels of organization of a living one is its start with a unit of analysis of what is alive an organism, also specific is its completion represented as a unit of development of a living form of life-a body. The conceptual filling of range of levels of an organization that is characteristic to a mental structure is appropriate of general categories of the structure human in accordance with the principle of systemicity has been proposed. The article also deals with the connection of the concept of a soul with categories that lie beyond the scope of psychological science per se, like philosophy. The necessity of the said action is justified by the historical context of the humanity's literary and social practices that include the notion of the soul. The article concludes with the outline of the future direction for theoretical research of the outlined problematic aimed at making space for the notion of the soul in psychological science and the system of its concepts. Overall, the work is dedicated to the efforts of bringing more clarity to the use of the concept of the soul within the existing paradigm of psychology.

Keywords: soul, individuality, organism, personality, subjectivity.

Геннадий Коваль, асп.

Запорожский национальный университет, Запорожье, Украина

\section{ПОНЯТИЙНО-КАТЕГОРИАЛЬНИЙ АСПЕКТ ПОНИМАНИЯ ТЕРМИНА "ДУША" КАК КАТЕГОРИИ ТЕОРЕТИЧЕСКОЙ ПСИХОЛОГИИ}

Рассмотрена проблематика категориального аспекта термина душа через призму принципа системности (организованности). Проблематика места категории душа в категориальном аппарате теоретической психологии показана через контекст общих категорий человековедения- организм, индивид, индивидуальность, личность, Я, субъект. Обозначено проблематику анализа и раскрытия содержательной нагрузки указанного ряда категорий, которая обусловлена применением к их анализу принципа детерминизма. Показана возможность разработки иерархического ряда категорий как уровней конкретизации (организации) психического по аналогии относительно подобного ряда уровней конкретизации (организации) живого. Обозначено, что для ряда уровней конкретизации живого является специфическим его начало единицей анализа живого - организмом, а завериение единицей (субъектом) развития живого- телом. Предложено понятийное наполнение ряда уровней организации психического общими категориями человековедения в соответствии с принципом системности.

Ключевые слова: душа, индивидуальность, организм, личность, субъектность.

Bulletin of Taras Shevchenko National University of Kyiv. Series "Psychology". № 1(10), pp. 55-60 (2019) УДК 159.9

DOI: https://doi.org/10.17721/BSP.2019.1(10).14
ISSN 1728-3817

(C) Taras Shevchenko National University of Kyiv, Publishing Center "Kyiv University", 2019

Едуард Крайніков, канд. психол. наук, доц., Євгеній Прокопович, канд. мед. наук, доц. Київський національний університет імені Тараса Шевченка, Київ, Україна Альона Баланюк, психолог Київ, Україна

\section{ОСОБЛИВОСтІ АДИКТИВНОї ОСОБИСТОСтІ}

Ми дослідили 50 осіб віком 18-25 років. Більшість респондентів є студентами вищих навчальних закладів. Нами був використаний такий психодіагностичний інструментарій: СМОЛ (скорочена адаптація ММPI), Методика діагностики копінгстратегій Хейма, методика Менделевича, Мічиганський алкогольний тест (MAST), Опитувальник ургентної залежності в адаптації Шибко. Респонденти демонструють деякі ознаки схильності, чи навіть чіткої наявності адиктивної поведінки. Вибір способу втечі від реальності виявився явищем культурним, тобто вибір того чи іншого адиктивного агента більшою мірою продиктований рекламою, суспільною думкою, продуктами мистецтва. Ці дані підтверджує щільний прямий зв'язок алкогольної залежності за опитувальником MAST та психопатії- коефіцієнт кореляції становить 0,27. 3а резуль-

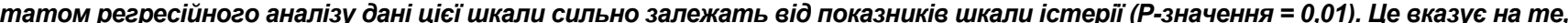
що прямо заявляти про вживання алкоголю та на наявність наслідків такого зловживання може особистість протестна, некомфортна, і така, що прагне перебільшити свої проблеми, привернути до себе увагу. Результати дослідження підтвердили наявні в літературі дані про притаманні адиктам імпульсивність, егоцентричність, депресивність і тривожність

Ключові слова: адикція, адиктивна поведеніка, ургентна залежність, психоактивні речовини.

Актуальність. За даними ВООЗ, вживання алкоголю і наркотиків $€$ причиною понад 200 соматичних та психічних порушень. Серед населення віком 2039 років приблизно $25 \%$ випадків смерті пов'язано 3 алкоголем. Уживання алкоголю $є$ однією із причин ранньої смерті чоловіків у віці 40-60 років. Установлено зв'язок між вживанням психоактивних речовин та захворюваністю на туберкульоз, ВІЛ/СНІД. Додатково до проблем зі здоров'ям, вживання психоактивних речовин та залежність від процесуальних адикцій завдає вагомих соціальних та економічних збитків окремим людям і суспільству в цілому [3]. Проблема адикцій стосується не тільки особистості самого адикта, а й сім'ї, соціального оточення, суспільства, оскільки така людина часто не може відповідально виконувати свої трудові, соціальні та сімейні обов'язки, потребує контролю, догляду та значних фрінансових витрат, особливо, якщо йдеться про гемблінг і наркотичну залежність. 
Організація дослідження та його результати. У нашому дослідженні взяли участь 50 осіб віком 18-25 років. Більшість респондентів $є$ студентами вищих навчальних закладів. Для дослідження особистісних якостей ми використали СМОЛ (Скорочений багатофракторний опитувальник для дослідження особистості) [4-5; 10]. Дослідити адаптивність осіб до життя було вирішено за допомогою Методики діагностики копінг-стратегій Е. Хейма [15]. Загальну схильність до адиктивної поведінки ми дослідили за допомогою методики В.Д. Менделевича [9]. Для визначення наявності хімічної соціально неприйнятної адикції ми обрали Мічиганський алкогольний тест [1; 6; 13-14], а для визначення наявності нехімічної, соціально прийнятної залежності- Опитувальник ургентної залежності в адаптації О. Л. Шибко [12]
У 22 досліджуваних виявлено ознаки стійкої хімічної або нехімічної адикції, в інших 28 осіб - схильність або ознаки тенденції хоча б по одному із видів адиктивної поведінки.

Загальну картину особистості досліджуваних дає стандартизований багатофакторний опитувальник СМОЛ $[2 ; 4-5 ; 10]$. Ми провели кореляційний аналіз усіх його показників (правдивість, самоконтроль, іпохондрія, депресія, істерія, психопатія, психастенія, паранояльність, шизоїдність, гіпоманія) та рівня адаптивності 3 показниками трьох тестів на виявлення адиктивної поведінки та схильності до неї. За тестом схильності до залежностей В.Д. Менделевича [9] ми отримали вражаючу картину (рис. 1).

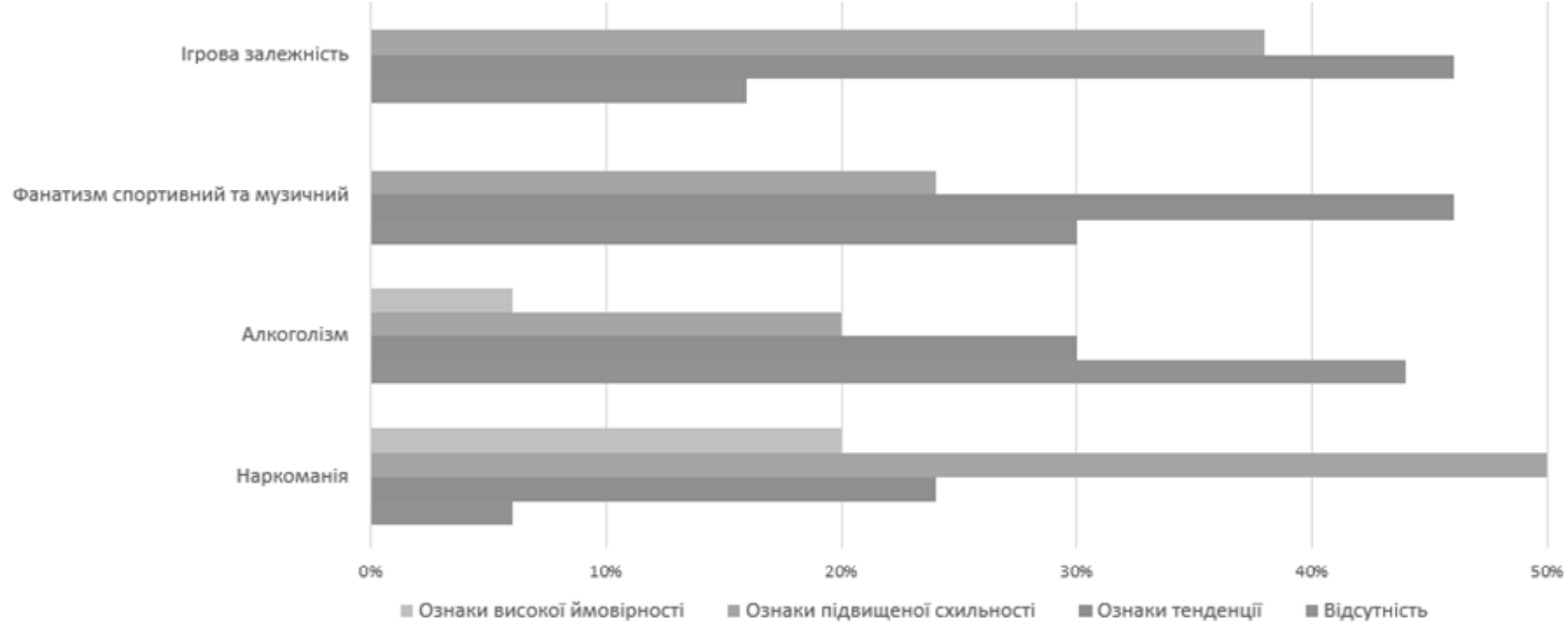

Рис. 1. Схильність до залежностей

Для математичного аналізу нами був використаний кореляційний та регресійний аналіз за допомогою програми Excel. Оцінка кореляції здійснювалася за такими критеріями: 0,1 - слабкий зв'язок, 0,3 - середній, 0,5сильний. Кореляційний аналіз загальної групи респондентів показав прямий зв'язок вище середнього між ургентною залежністю та іпохондрією (коефріцієнт кореляції 0,38), гіпоманією (коефіцієнт кореляції 0,32), істерією (коефіцієнт кореляції 0,33); прямий зв'язок середньої сили зі шкалами брехні, депресії, паранояльності, психостенії та шизоїдності (показники кореляції $0,23-0,28)$ (рис. 2).

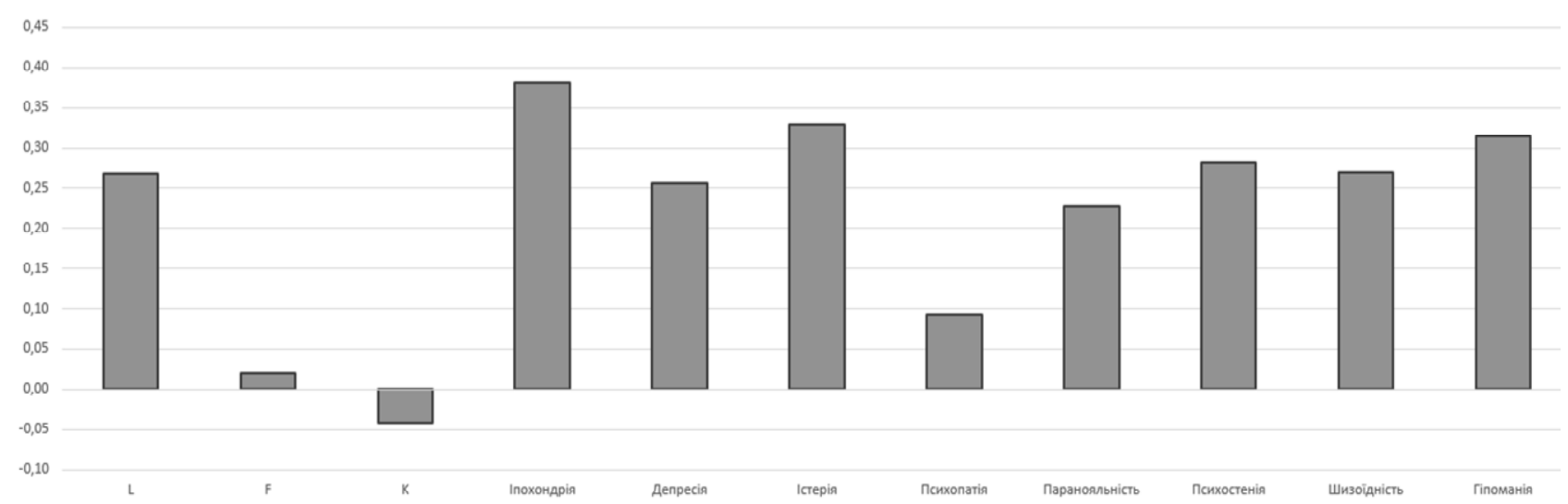

Рис. 2. Кореляційний зв'язок ургентної залежності з показниками тесту СМОЛ

Такі результати можуть вказувати на те, що у осіб 3 ургентною залежністю спостерігається високо розміщений профіль та наявна невротична тріада з негативним нахилом, що свідчить про високий ризик поведінкових реакцій.Підвищеною $є$ ймовірність невротичних розладів; наявні емоційні ускладнення, гострі переживання, занепокоєння, тривога, невпевненість, труднощі у спілкуванні, неприємні відчуття, соматичні розлади. Для пацієнтів із невротичною тріадою характерна висока емоційна лабільність, прагнення до спілкування [7]. Можна припустити, що емоційним, тривожним, сенситивним особам, що прагнуть встигнути все і одразу, але страждають від відчуття, що встигли зробити недостатньо, властива залежність від постійного браку часу. На нашу думку, це добре відображає вікові особливості досліджуваних осіб, оскільки до них ставиться величез- 
на кількість вимог. Про це також свідчить, що 14 \% респондентів страждають від сильної ургентної адикції, а $72 \%$ - від помірної ургентної адикції (тобто майже всі). Це може бути ознакою соціальної схвалюваності явища ургентної залежності у суспільстві.

Алкогольну залежність ми досліджували за допомогою двох методик. Одна - тест MAST $[1 ; 6 ; 14]$, який не має механізмів захисту від бажання особистості виглядати краще і повністю залежить від суб'єктивного уявлення особистості про себе. Друга - шкала схильності до алкогольної залежності В.Д. Менделевича [9], де питання $€$ не очевидними, $є$ зворотні шкали і респонденту важче вибрати соціально прийнятний варіант відповіді. Також ми провели кореляційний аналіз кожної шкали зі шкалою брехні у тесті СМОЛ.

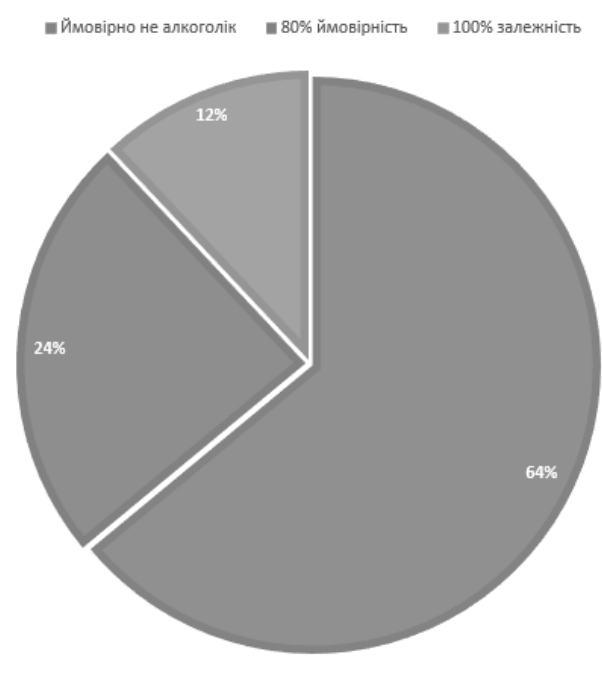

Рис. 3. Кількість осіб,

залежних від алкоголю за тестом MAST

На рис. 3 продемонстровано, що $12 \%$ респондентів $€$ залежними від алкоголю, а 24 \% мають високу ймовірність такої залежності. Цікаво, що результати за цим тестом мають достатньо щільний непрямий кореляційний зв'язок зі шкалами брехні $L(0,31)$ і корекції $K(0,31)$, та щільний прямий зв'язок зі шкалою достовірності $F$ $(0,32)$. Ці дані демонструють, що чим більше респондент свідомо та підсвідомо контролював свої відповіді та намагався постати у позитивному світлі, тим нижчий показник у нього за тестом на алкоголізм за методикою MAST [14]. Кореляційний зв'язок між шкалою L та схильністю до алкоголю за методикою В.Д. Менделевича дещо відрізняється $(-0,22)$ і також $€$ непрямим. За останньою методикою спостерігається зв'язок із паранояльністю $(0,26)$ і з MAST $(0,39)$. Регресійний аналіз показав, що на результати тесту MAST найбільший вплив має шкала істерії (Р-значення $=0,01)$, тоді як на результати тесту схильності до алкогольної залежності найбільше впливає показник адаптивності (Pзначення $=0,03)$ та шкала депресії $($ Р-значення $=0,26)$. Шкала паранояльності майже не впливає на показники шкал алкогольної залежності обох тестів.

Результати тесту MAST ставлять під сумнів вплив шкали істерії. Відмінності $€$ й у кореляційних зв'язках результатів цих двох тестів на алкоголізм зі шкалою психопатії. За тестом MAST, коефріцієнт кореляції становить 0,27 , а за тестом схильності до алкогольної залежності- лише 0,04 , тобто кореляційного зв'язку майже немає. Ми спробували детальніше розібрати цей фракт через регресійний аналіз і виявилося, що на результати за шкалою психопатії найбільше впливає MAST (Р-значення = 0,05), тоді як Тест на схильність до алкогольної залежності взагалі не корелює із психопатією (Р-значення $=0,9)$. Шкала психопатії демонструє небажання особистості наслідувати загальноприйняті норми та правила, високі показники притаманні протестним, некомформним особам. Звідси можна зробити припущення, що саме такі особи не приховували своєї алкогольної залежності, а ті респонденти, що хвилюються за свій суспільний імідж, намагаються обирати більш соціально прийнятні відповіді. Найсильніший зв'язок виявився між показниками тесту схильності до алкогольної залежності та гіпоманією - коефіцієнт кореляції становить 0,35, що свідчить про підвищений фон настрою та високий рівень активності осіб, що мають таку схильність. За тестом MAST, цей зв'язок $\epsilon$, але слабший $(0,15)$. Доречно помітити, що, скоріше за все, алкогольна залежність за цими двома тестами виявлена у різних осіб, що підтверджує слабкий кореляційний зв'язок між показниками MAST та Тесту на схильність до алкогольної залежності $(0,02)$.

Найбільш вражаючі результати за шкалою схильності до наркоманії (50\% респондентів) показали ознаки підвищеної схильності до вживання наркотиків. Це вказує на схильність до залежної поведінки вище середньої, тобто переважають ті якості, які більшою мірою свідчать про спрямованість на вживання і ризик розвитку психологічної залежності. У 20 \% респондентів ознаки високої ймовірності. Ця категорія характеризується високою схильністю до залежної поведінки. У респондентів спостерігається висока спрямованість на вживання наркотичних речовин, позитивне ставлення до залежності та риси особистості, які значно збільшують ризик проблемної поведінки [8]. У 24 \% респондентів ознаки схильності до залежної поведінки середньої вираженості. Це свідчить про те, що у респондентів за певних соціальних умов $є$ ризик розвитку залежності. I лише незначні $6 \%$ не мають стосунку до вживання наркотиків. За результатами кореляційного аналізу ми отримали графрік сили кореляції між схильністю до наркотичної залежності та особистісними характеристиками за методикою СМОЛ (рис. 4).

Найбільшим $€$ коефріцієнт кореляції між схильністю до наркотичної залежності та шкалою брехні (середній непрямий зв'язок - 0,18), що свідчить про небажання осіб, які мають таку схильність, давати правдиві відповіді. Наявність слабких кореляційних зв'язків майже з усіма шкалами СМОЛ, скоріше за все, демонструє кореляцію схильності до наркотичної залежності та "утоплених" граффіків. Такий граффік частіше за все демонструє установче ставлення до тестування. Але регресійний аналіз показав деякий вплив на наркотичну схильність шкали депресії (Р-значення $=0,28)$ та психастенії (Р-значення =0,23). Можна припустити, що схильність до вживання наркотиків пов'язана із сенситивністю, чуттєвістю та депресивністю особистості, що може свідчити про пасивність особистісної позиції, коли провідною мотиваційною потребою стає уникнення невдачі. Для подібних осіб властиві такі особливості: високий рівень усвідомлення наявних проблем через призму незадоволеності й песимістичної оцінки своїх перспектив, схильність до роздумів, інертність у прийнятті рішень, виражена глибина переживань, аналітичний склад розуму, скептицизм, самокритичність, деяка невпевненість у своїх можливостях [7]. Загальна картина більшості профілів демонструє небажання розкриватися - це люди стримані, що мають розвинений внутрішній світ, на що також вказує наявність слабкої кореляції між схильністю до наркотичної залежності та шкалами шизоїдності $(0,10)$ та паранояльності $(0,12)$ за СМОЛ. Такої самої сили, але непрямий зв'язок, спо- 
стерігається зі шкалами істерії та депресії. Майже відсутній кореляційний зв'язок схильності до наркотичної залежності та шкали психопатії.

У жодного із респондентів не виявлено високу ймовірність залежності від комп'ютерних ігор, у $47 \%$ - ознаки тенденції та у 38 \% - ознаки підвищеної схильності. За даними кореляційного аналізу виявлено прямий щільний зв'язок зі шкалами іпохондрії $(0,25)$, депресії $(0,26)$ та паранояльності $(0,25)$.

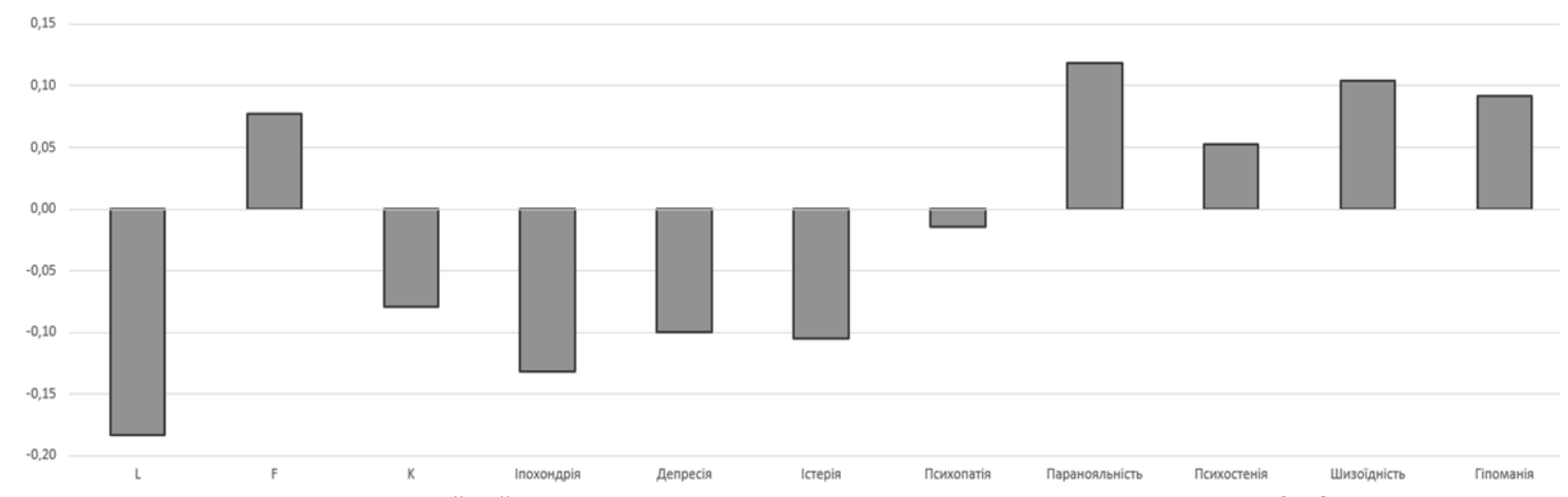

Рис. 4. Кореляційний зв'язок між схильністю до наркоманії та показниками шкал СмОЛ

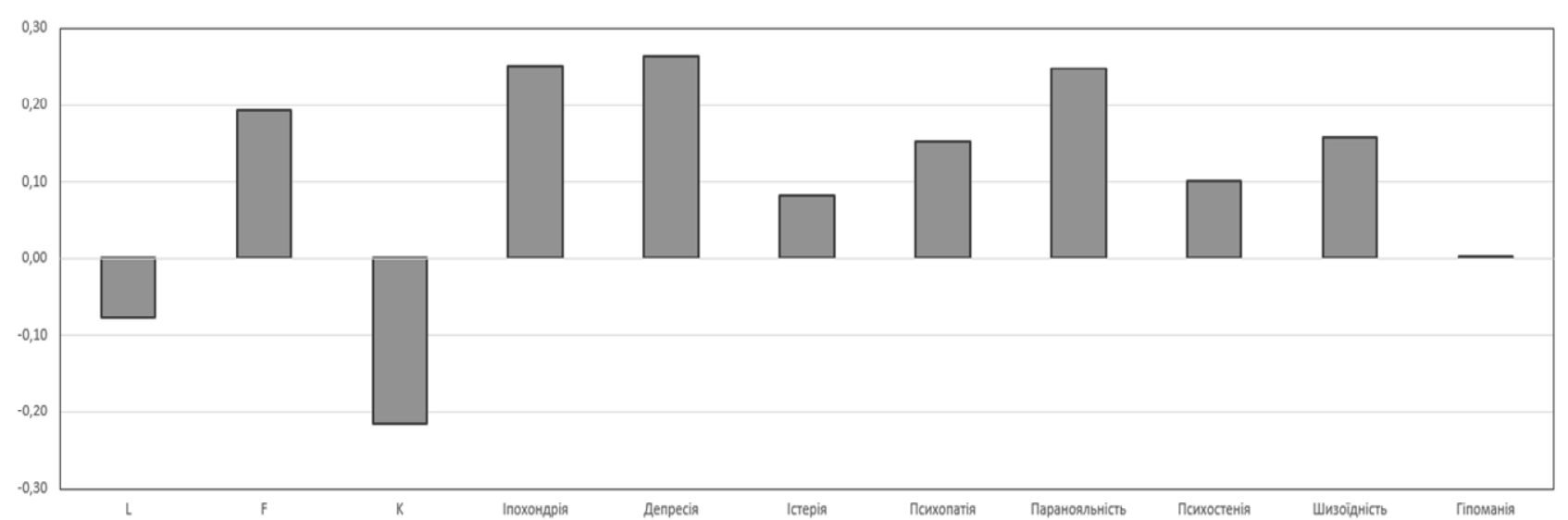

Рис. 5. Кореляційний зв'язок схильності до залежності від комп'ютерних ігор зі шкалами Смол

Можна припустити, що чим вищими є емоційна лабільність, тривожність та депресивність особистості, тим більша ймовірність схильності до залежності від комп'ютерних ігор. Зазначимо, що ця залежність відрізняється від інших яскравим віртуальним світом, який дає особі можливість сховатися в ньому від негараздів. Ю. Стародубцев спостерігає в осіб із комп'ютерною залежністю знижений фон настрою, дратівливість, схильність до афекту, тривожні вияви, гіперестезії, порушення циклу сон - неспання та астенічні вияви. Для осіб із розладами адаптації та комп'ютерною залежністю притаманні клінічні вияви тривоги та депресії, важкі депресивний і тривожний епізоди; високі рівні ситуативної й особистісної тривожності, надмірна нервовопсихічна напруга. Тобто, можемо зробити висновок, що, як комп'ютерна залежність, так і залежність від комп'ютерних ігор міцно пов'язані із тривогою та депресією. Припускаємо, що ці залежності дуже споріднені й між ними важко провести чітку межу.

Окремої уваги вартий коефіцієнт кореляції схильності до комп'ютерних ігор зі шкалою корекції К $(0,21)$ - ідеться про відсутність відвертості, прагнення приховати дефекти свого характеру та наявність проблем і конфоліктів.

Так само як і зі схильністю до залежності від комп'ютерних ігор, ніхто з респондентів не показав ознаки високої ймовірності схильності до спортивного та музичного фанатизму, у 30 \% респондентів така схильність взагалі відсутня, 48 \% опитуваних демонструють лише ознаки тенденції до такої схильності. Напрошу- ється висновок про те, що цей вид залежності менше за все загрожує особам раннього дорослого віку.

Основна гіпотеза, що напрошується у зв'язку з такими результатами, - про те, що спортивний і музичний фанатизм, у даному віковому періоді, був більшою мірою притаманний наприкінці XX ст. Спостерігається слабкий кореляційний зв'язок із результатами за шкалою депресії $(0,13)$, та непрямий зв'язок зі шкалою гіпоманії $(-0,07)$. Можна зробити припущення, що спортивний та музичний франатизм більшою мірою схильний особистості при зниженні настрою й інтересу до життя.

За результатами математичного аналізу ми розділили всіх респондентів на дві групи та провели кореляційний аналіз двох груп. Першу групу становили особи, в яких хоча б за однією методикою виявлено залежність, другу групу - особи, у яких залежностей не виявлено або $є$ лише тенденції до адиктивної поведінки. Обидві групи було порівняно за допомогою двофакторного t-тесту з різними дисперсіями.

Виходячи з цих даних, група залежних респондентів та таких, що не мають ознак наявної залежності, відрізняється за шкалами депресій, психастенії, паранояльності, шизоїдності та гіпоманії. Середні показники за цими шкалами вищі у представників групи, що показала наявну адикцію. Таким чином, можна зробити припущення, що адикти є більш емоційно лабільними, сенситивними, вразливими. Їм притаманна імпульсивність та дратівливість. Адикти мають більш високий рівень креативності, часто перебувають у власному ілюзорному або віртуальному світі. 


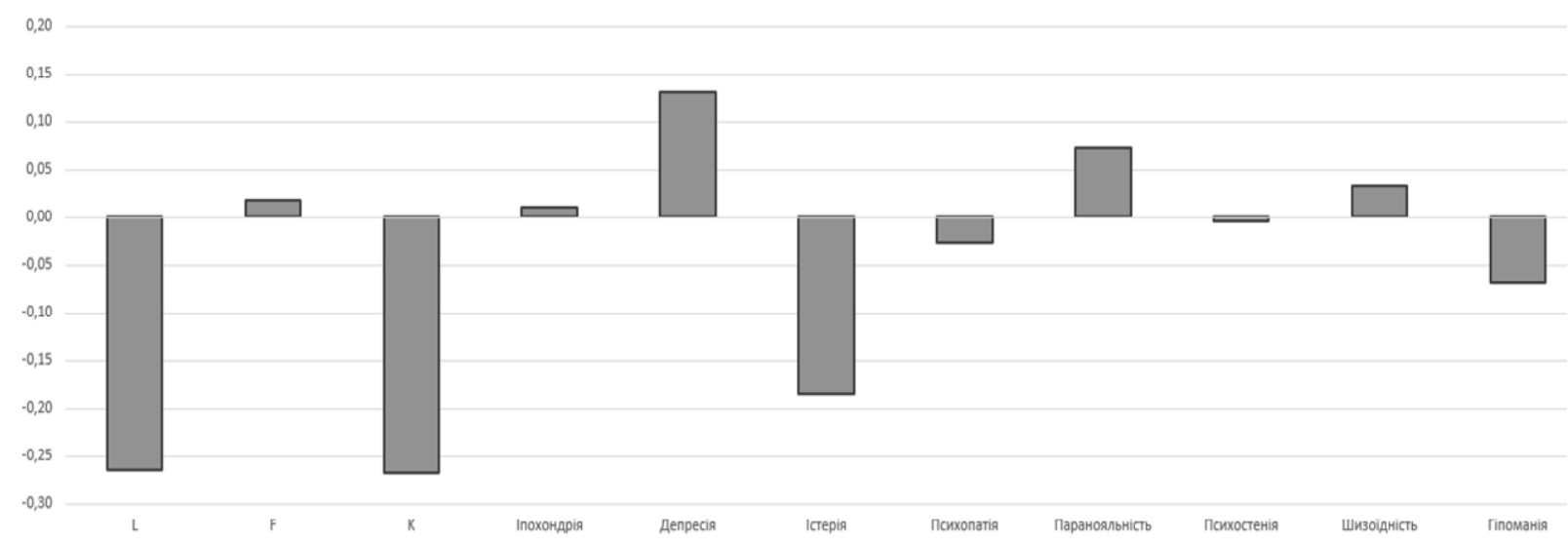

Рис. 6. Кореляційний зв'язок схильності до спортивного та музичного фанатизму і результатів тесту Смол

Різниця двох груп за t-критерієм Стьюдента

Таблиця 1

\begin{tabular}{|l|c|c|}
\hline \multicolumn{1}{|c|}{ Шкала } & $\mathbf{t}$-статистика & $\mathbf{P}(\mathbf{T}<\mathbf{t})$ двостороннє \\
\hline Іпохондрія & 2,02 & 0,049 \\
\hline Депресія & 1,06 & 0,293 \\
\hline Істерія & 1,7 & 0,096 \\
\hline Психопатія & 1,8 & 0,072 \\
\hline Психастенія & 1,4 & 0,151 \\
\hline Паранояльність & 3,9 & 0,0003 \\
\hline Шизоїдність & 2,3 & 0,023 \\
\hline Гіпоманія & 2,4 & 0,017 \\
\hline
\end{tabular}

Такі висновки є дуже відносними, оскільки ми могли переконатися на двох різних тестах на алкогольну залежність, як відрізняються результати одних і тих самих респондентів. Але результати дослідження й обрахунки показують деякі тенденції, що загалом підтверджують літературні дані про особистість адикта.

Варта уваги сила кореляційного зв'язку між різними видами залежності. У літературі часто йдеться про поєднання хімічних та нехімічних адикцій, а також потенціал одних залежностей замінювати інші [11]. Так, в ургентної залежності $є$ слабка пряма кореляція з алкогольною залежністю та залежністю від комп'ютерних ігор $(0,16)$, тоді як із наркоманією дуже слабо виражений непрямий зв'язок $(-0,07)$. Тобто, можемо припустити, що ургентний адикт як хімічну залежність, скоріше за все, обере алкоголізм, але точно не наркоманію. Алкогольна залежність має сильну пряму кореляцію зі спортивним та музичним фанатизмом $(0,47)$. На нашу думку, це може свідчити про сумісність цих адикцій у певних субкультурних молодіжних групах, та, скоріше за все, ідеться про франатизм як такий, - не лише музичний та спортивний.

\section{Список використаних джерел}

1. Бобров А. Е. Алкогольный скрининг-тест: его валидность и структура / А. Е. Бобров, А. Н. Шурыгин // Психологическая диагностика при нервно-психических и психосоматических заболеваниях. - Л., 1985. C. 33-36.

2. Бурлачук Л. Ф. Словарь-справочник по психодиагностике / Л. Ф. Бурлачук, С. М. Морозов. - СПб. : Питер, 1999. - 528 с.

3. Даулинг С. Психология и лечение зависимого поведения / С. Даулинг. - М. : Независимая фрирма "Класс", 2000. - 228 с.

$$
\text { 4. Зайцев В. П. Вариант психологического теста Mini- }
$$$$
\text { Mult / В. П. Зайцев // Психолог. журн. - 1981. - № 3. - С. 118-123. }
$$

5. Зайцев В. П. Психологический тест СМОЛ / В. П. Зайцев [Електронний ресурс]. - Режим доступу: http://clinical-psy.ru/wpcontent/uploads/Zaytsev2.pdf.

6. Линский И. В. Система AUDIT-подобных тестов дпя комплексной оценки аддиктивного статуса индивида и популяции / И. В. Линский, А. И. Минко, А. Ф. Артемчук та ін. // Новости укр. психиатрии. - Киев ; Харьков, 2009. [Електронний ресурс]. - Режим доступу: http://www.psychiatry.ua/articles/paper313.htm.

7. Мак-Вильямс Н. Психологическая диагностика: Понимание структуры личности в клиническом процессе / Н. Мак-Вильямс. - М. : Независимая фирма "Класс". - 2015. - 592 с.

8. Максимова Н. Ю. Психологія адиктивної поведінки: навч. посіб. / Н. Ю. Максимова. - К. : ВПЦ "Київський університет", 2002. - 308 с.
9. Менделевич В.Д. Руководство по аддиктологии / В. Д. Менделевич. - СПб. : Речь, 2007. - 768 с.

10. Собчик Л. Н. СМИЛ. Стандартизированный многофакторный метод исследования личности / Л. Н. Собчик. - СПб. : Речь, 2004. - 224 с.

11. Старшенбаум Г. В. Независимость. Как избавиться от психологической или химической зависимости / Г. В. Старшенбаум. - М. : ООО "Издательство АСТ", 2018. - 480 с.

12. Шибко О. Л. Ургентная аддикция как форма аддиктивного поведения личности / О. Л. Шибко // Психолог. журн. - 2006. - № 3(11). C. $65-68$.

13. Hallinan P. Factor structure and validity of the Alcohol Use Disorders Identification Test (AUDIT) in a sample of mentally disordered offenders / P. Hallinan, S. McGilloway, M. Dempster, \& M. Donnelly // The Journal of Forensic Psychiatry \& Psychology. - 2011. - 22. - P. 586-602.

14. Hedlund J. The Michigan Alcoholism Screening Test (MAST): A comprehensive review / J. Hedlund \& B. Vieweg // Journal of Operational Psychiatry. - 1984. - 15. - P. 55-64.

15. Heim E.Coping und Adaptivität: Gibtesgeeignetes oderungeeignetes Coping? / E. Heim // Psychother. med. Psychol. -1988. - Vol. 38. - P. 8-18.

References

1. Bobrov A. E. Alkoholnyi skrynynh-test: eho valydnost y struktura/ A. E. Bobrov, A. N. Shuryhyn // Psykholohycheskaia dyahnostyka pry nervno-psykhycheskykh y psykhosomatycheskykh zabolevanyiakh. - L., 1985. - S. 33-36.

2. Burlachuk L. F. Slovar-spravochnyk po psykhodyahnostyke / L. F. Burlachuk, S. M. Morozov. - SPb. : Pyter, 1999. - 528 s.

3. Daulynh S. Psykholohyia y lechenye zavysymoho povedenyia / S. Daulynh. - M. : Nezavysymaia fyrma "Klass", 2000. - $228 \mathrm{~s}$.

4. Zaitsev V. P. Varyant psykholohycheskoho testa Mini-Mult / V. P. Zaitsev // Psykholohycheskyi zhurnal. - 1981/ - № 3. - S. 118-123.

5. Zaitsev V. P. Psykholohycheskyi test SMOL / V. P. Zaitsev [Elektronnyi resurs] Kod dostupu: http://clinical-psy.ru/wp-content/uploads/Zaytsev2.pdf

6. Lynskyi Y. V. Systema AUDIT-podobnbkh testov dlia kompleksnoi otsenky addyktyvnoho statusa yndyvyda y populiatsyy/Y. V. Lynskyi, A. Y. Mynko, A. F. Artemchuk ta in. // Novosty ukraynskoi psykhyatryy. Kyev-Kharkov, 2009. [Elektronnyi resurs]. Kod dostupu: http://www.psychiatry.ua/articles/paper313.htm.

7. Mak-Vyliams N. Psykholohycheskaia dyahnostyka: Ponymanye struktury lychnosty $v$ klynycheskom protsesse / N. Mak-Vyliams. - M. : Nezavysymaia fyrma "Klass". - 2015. - $592 \mathrm{~s}$.

8. Maksymova N. Yu. Psykholohiia adyktyvnoi povedinky: Navch. posib. / N. Yu. Maksymova. - K. : Vydavnycho-polihrafichnyi tsentr "Kyivskyi universytet", 2002. - $308 \mathrm{~s}$.

9. Mendelevych V. D. Rukovodstvo po addyktolohyy / V. D. Mendelevych. - SPb. : Rech, 2007. - 768 s.

10. Sobchyk L. N. SMYL. Standartyzyrovannыi mnohofaktornыi metod yssledovanyia lychnosty / L. N. Sobchyk. - SPb. : Rech, 2004 - 224 s.

11. Starshenbaum H. V. NeZavysymost. Kak yzbavytsia ot psykholohycheskoi yly khymycheskoi zavysymosty / H. V. Starshenbaum. M. : OOO "Yzdatelstvo AST", 2018. - $480 \mathrm{~s}$.

12. Shybko O. L. Urhentnaia addyktsyia kak forma addyktyvnoho povedenyia lychnosty / O. L. Shybko // Psykholohycheskyi zhurnal. - 2006, № $3(11)$. - S. 65-68. 
13. Hallinan P. Factor structure and validity of the Alcohol Use Disorders Identification Test (AUDIT) in a sample of mentally disordered offenders / P. Hallinan, S. McGilloway, M. Dempster, \& M. Donnelly // The Journal of Forensic Psychiatry \& Psychology. - 2011, 22. - P. 586-602.

14. Hedlund J. The Michigan Alcoholism Screening Test (MAST): A comprehensive review / J. Hedlund \& B. Vieweg // Journal of Operational Psychiatry. - 1984, 15. - P. 55-64.

Eduard Krainikov, Ph.D., Assoc. Prof.

Eugeniy Prokopovich, Ph.D., Assoc. Prof.

Taras Shevchenko National University of Kyiv, Kyiv, Ukraine

Alona Balanyuk, psychologist

Kyiv, Ukraine
15. Heim E. Coping und Adaptivität: Gibt es geeignetes oder (1988, Vol. 38. - P. 8-18.

Надійшла до редколегії 22.06.19

\section{FEATURES OF ADDICTIVE PERSONALITY}

We surveyed 50 people between the ages of 18 and 25, most of respondents are college students. We used the following assessment tools: SMOL (abbreviated adaptation of MMPI), Heim's test for coping strategies, Mendelevich's methodic, Michigan Alcohol Test (MAST), Urgent Dependence Questionnaire in Shibko's adaptation. Respondents show some signs of predisposition, or even a clear presence of addictive behavior. Choosing a way to escape from reality was a cultural phenomenon, that is, the choice of an addictive agent is more dictated by advertising, public opinion, and art products. This data confirms the close direct relationship between alcohol dependence (according to MAST) and psychopathy - a correlation coefficient of 0.27 . According to the regression analysis, the data of this scale strongly depend on the indicators of the hysteria scale $(P$-value $=0.01)$. This indicates that expressing alcohol and the consequences of such abuse can make a person protesting, uncomfortable, and seeking to exaggerate their problems and attract attention. The results of the study confirmed the literature data about self-centered, depressive, and anxious fetures of addictive personality. We can assume that the higher the emotional lability, anxiety and depressive personality, the greater the likelihood of addiction to computer games. It is worth noting that this dependency is different from the other vivid virtual world, which gives the person the opportunity to hide in him from the troubles. For people with adaptation disorders and computer addiction, clinical manifestations of anxiety and depression, severe depressive and anxiety episodes are common; high levels of situational and personal anxiety, excessive nervous and mental stress. That is, we can conclude that both computer addiction and gaming addiction are strongly linked to anxiety and depression. We assume that these dependencies are very closely related and that it is difficult to draw a clear boundary. In addition to health problems, psychoactive substance use, and addiction to procedural addiction, it causes significant social and economic damage to individuals and society as a whole.

Keywords: addiction, addictive behavior, urgent dependence, psychoactive substances.

Эдуард Крайников, канд. психол. наук, доц.

Евгений Прокопович, канд. мед. наук, доц.

Киевский национальный университет имени Тараса Шевченко, Киев, Украина

Алёна Баланюк, психолог

Киев, Украина

\section{ОСОБЕННОСТИ АДДИКТИВНОЙ ЛИЧНОСТИ}

Мы исследовали 50 человек в возрасте 18-25 лет. Большинство респондентов являются студентами высших учебных заведений. Нами был использован такой психодиагностический инструментарий: СМОЛ (сокращенная адаптация ММРI), Методика диагностики копинг-стратегий Хейма, методика Менделевича, Мичиганский алкогольный тест (МАST), Опросник ургентной зависимости в адаптации Шибко. Респонденты демонстрируют некоторые признаки склонности, или даже четкого наличия аддиктивного поведения. Выбор способа ухода от реальности оказался явлением культурным, то есть выбор того или иного аддиктивного агента в большей степени продиктован рекламой, общественным мнением, продуктами искусства. Эти данные подтверждают плотную прямую связь алкогольной зависимости по опроснику MAST и психопатии - коэффициент корреляции составляет 0,27. По результатам регрессионного анализа, данные этой шкалы сильно зависят от показателей шкалы истерии (P-значение = 0,01). Это указывает на то, что прямо заявлять об употреблении алкоголя и наличии последствий такого злоупотребления может личность протестная, комфортная, и такая, которая стремится преувеличить свои проблемы, привлечь к себе внимание. Результаты исследования подтвердили имеющиеся в литературе данные о присущих аддиктам импульсивности, эгоцентричности, депрессивности и тревожности.

Ключевые слова: аддикция, аддиктивная поведеника, ургентная зависимость, психоактивные вещества.

Bulletin of Taras Shevchenko National University of Kyiv.

Series "Psychology". № 1(10), pp. 60-63 (2019)

УДК 159.9.016

DOI: https://doi.org/10.17721/BSP.2019.1(10).15
ISSN 1728-3817

(c) Taras Shevchenko National University of Kyiv,

Publishing Center "Kyiv University", 2019

Олена Литвиненко, канд. психол. наук, старш. викл. Київський університет імені Бориса Грінченка, Київ, Україна

\section{ПРАКТИЧНІ АСПЕКТИ РОБОТИ ПСИХОЛОГА 13 ВНУТРІШНЬО ПЕРЕМІЩЕНИМИ СТУДЕНТАМИ ПЕРШОГО КУРСУ}

Представлено концепцію комплексної психологічної адаптації першокурсників до студентського життя. Узагальнено теорії адаптивності юнаків і підлітків та концепції їх пристосування до нових умов життя й діяльності. Описано результати емпіричного дослідження індивідуально-психологічних якостей першокурсників, особливостей їх соціальної взаємодіі та академічної мотивації. Проаналізовано досвід психологічного супроводу процесу адаптації студентів, які є внутрішньо переміщеними, до навчання у ЗВО. Визначено їхні провідні особистісні та характерологічні особливості, способи пристосування до ситуації та реагування на несприятливі впливи із зовнішнього середовища. Окреслено перспективне коло досліджень у сфері психологічного супроводу та підтримки внутрішньо переміщених студентів.

Ключові слова: адаптація першокурсників, внутрішньо переміщені особи, адаптаційні ресурси, адаптаційний потенціал, навчально-виховний процес.

Постановка проблеми. Історичні процеси, що відбуваються в українькому суспільстві, зумовлюють появу значної кількості внутрішньо переміщених осіб - людей, які через військові дії на території їх рідних населених пунктів змушені були покинути власні домівки та розпочати нове життя на новому місці. Специфіка та тривалість адаптаційного періоду і призвичаєння їх до нових умов життя залежить від численних факторів: індивідуально-психологічних властивостей особистості, її адаптаційних ресурсів, особливостей функціонування емоційно-вольової сфрери, інтегрованості до суспільної та професійної діяльності, вікової категорії. Особливо травматичним адаптаційний період може стати для підлітків, у житті яких переміщення на нове місце проживання збігається зі вступом до вищого навчального закладу та початком студентського життя. Тому, принципового значення набуває цілеспрямована та організована робота різних спеціалистів (психологів, педагогів, кураторів та т'юторів), спрямована на інтеграцію таких підлітків у студентську спільноту та на елімінацію в них негативних виявів, пов'язаних із вимушеним переселенням. 